\title{
DESEJO DE LUZ: O CRISTIANISMO E O SURGIMENTO DA FILOSOFIA MODERNA EM LUDWIG FEUERBACH
}

\section{A DESIRE FOR LIGHT: CHRISTIANITY AND THE EMERGENCE OF MODERN PHILOSOPHY IN LUDWIG FEUERBACH}

Chrysantho Figueiredo*

RESUMO: este trabalho é uma resenha da introdução do livro de Ludwig Feuerbach Geshichte der Neuern Philosophie von Bacon bis Spinoza. O texto original é em alemão; a resenha, em português. Apresentamos, entretanto, em anexo, a tradução do texto, também inédita e original. Em A Essência do Cristianismo, de 1841, Feuerbach apresenta de maneira mais acabada sua versão do humanismo radical que entusiasmou os jovens hegelianos de sua geração. Entretanto, é entre 1833 e 1838 que Feuerbach formula seu próprio ponto de vista filosófico a partir da crítica sistemática dos principais sistemas filosóficos da modernidade. História da Filosofia Moderna de Bacon a Spinoza, obra de 1833, é a primeira das obras histórico-filosóficas de Feuerbach que, além da crítica aos filósofos apresentados no próprio título da obra, traz também a visão singular feuerbachiana da história como um todo, mostrando como a filosofia moderna surge das contradições inerentes ao espírito religioso cristão.

PALAVRAS-CHAVE: Cristianismo. Crítica da Religião. Crítica Filosófica. História da Filosofia Moderna. Ludwig Feuerbach.

ABSTRACT: This is a review of Ludwig Feuerbach's book introduction Geshichte der Neuern Philosophie von Bacon bis Spinoza. The original text is in German, the review is in Portuguese. However, we present here, attached, the translated text, also unpublished and original. In 1841's The Essence of Christianity, Feuerbach presents in a most complete way his own version of the radical humanism which excited the young hegelians of his generation. However, it is between 1833 and 1838 that Feuerbach formulates his own philosophical point of view from the critique of the major philosophical systems of modernity. The History of Philosophy from Bacon to Spinoza, published in 1833, is the first of his historicalphilosophical works which, apart from the critique of the philosophers indicated by the title, presents also a singular feuerbachian vision of history as a whole, showing how modern philosophy emerges from the inherent contradictions of the Christian religious spirit.

KEYWORDS: Christianity. Critique of Religion. History of Modern Philosophy. Ludwig Feuerbach. Philosophical critique.

\footnotetext{
* Graduado em Direito pela Faculdade de Direito de Curitiba - UNICURITIBA, 2008. Mestrando no Programa de Pós-graduação em Filosofia da Universidade Federal do Paraná - UFPR, 2012. E-mail: chrysantho@gmail.com
} 


\section{INTRODUÇÃO}

Ludwig Andreas Feuerbach nasceu em Landshut, na Bavária, em 1804, ano da morte de Immanuel Kant e da revolução haitiana liderada por Touissant L'Ouverture. O pai de Feuerbach foi o jurista Paul Johann Anselm Feuerbach ${ }^{1}$, um dos precursores da teoria moderna do tipo penal, autor do Código Penal bávaro e tutor legal do menino Kaspar Hauser, criança que havia sido mantida num porão escuro desde bebê, sem qualquer contato humano, a não ser com um homem que periodicamente lhe trazia pão e água. A atrocidade do caso pautou os noticiários da época e deu protagonismo a Paul Johann Anselm Feuerbach, que ficou incumbido de investigar as medidas legais para a solução do caso, do que resultou a obra de sua autoria Kaspar Hauser: exemplo de um crime na vida mental de um homem (FEUERBACH, P. J. A., 1832). ${ }^{2}$

Além do pai, todos os quatro irmãos de Ludwig Feuerbach foram intelectuais que se destacaram nos campos mais distintos do conhecimento: da matemática à filologia oriental, incluindo direito, história e filosofia. O sobrenome dos Feuerbach marcou a história intelectual da Alemanha no século XIX, sendo o filósofo o mais conhecido dentre os irmãos.

Educado para ser teólogo desde a adolescência no ginásio de Ansbach, Ludwig Feuerbach decidiu ingressar na Faculdade de Filosofia de Berlim no início da década de 1820. A cidade fora apelidada por ele de "Belém de um novo mundo" (BRECKMAN, 2001, p. 93), por conta da efervescência cultural estimulada em grande parte pelas aulas de Hegel e de Schleiermacher. Em 1824, finalmente conseguiu matricular-se no curso, revelando especial interesse pelas lições de filosofia da religião ministradas por Hegel. ${ }^{3}$

Quando jovem, Feuerbach revelou sinais de uma forte influência do pensamento hegeliano, como na dissertação de 1828, De Rationae, Una, Universali, Infinita. Durante a

\footnotetext{
${ }^{1}$ A vida de Paul Johann Anselm Feuerbach foi relatada numa biografia (Paul Johann Anselm Feuerbach: ein Juristenleben) escrita por ninguém menos que Gustav Radbruch (1934).

${ }^{2}$ Utilizamos como referência a tradução em inglês que, por motivos editoriais, alterou substancialmente o subtítulo da obra. Aqui, optamos por traduzir literalmente o título do original em alemão (Kaspar Hauser: Beispiel eines Verbrechens am Seelenleben des Menschen).

${ }^{3}$ Hegel deu quatro versões de seu curso sobre a filosofia da religião. A primeira versão aconteceu em 1821, com os cursos subsequentes acontecendo em 1824, 1827 e 1831, ano da morte de Hegel. Algumas anotações utilizadas para a composição em três volumes de Lições sobre a Filosofia da Religião foram escritas por nomes importantes do hegelianismo, como é o caso das notas de 1831 de David Friedrich Strauss. Strauss ficou conhecido por um polêmico estudo crítico das escrituras neotestamentárias, A Vida de Jesus: criticamente analisada. Nele, Strauss pretende provar que não apenas os mitos cristãos são inverossímeis como o próprio Cristo histórico jamais teria existido, sendo apenas a criação fantástica de uma forma de discurso historicamente dominante entre os hebreus do Império Romano, a chamada linguagem "mito-poética". A própria interpretação crítica do discurso mito-poético já havia sido desenvolvida, segundo Strauss, por um intelectual judeu com cidadania romana, Filo de Alexandria, muito admirado pelos doutores da recém-nascida igreja cristã (STRAUSS, 2005).
}

Revista da Faculdade de Direito - UFPR, Curitiba, vol. 60, n. 1, jan./abr. 2015, p. 247-269. 
década de 1830, Feuerbach se distanciará progressivamente da filosofia hegeliana (WARTOFSKY, 1977, p. 28-49). Nessa época, ele adere a uma concepção radicalmente crítica da religião cristã, chamada por John Edward Toews de "humanismo dialético" (TOEWS, 1989, passim), ao se referir à filosofia dos jovens hegelianos dos anos de 1820 a 1840. A versão feuerbachiana desse humanismo será apresentada de maneira mais completa em sua obra máxima, A Essência do Cristianismo, de 1841.

O que pouco se comenta é que a A Essência do Cristianismo vem precedida de um extenso trabalho de formulação sobre a história da filosofia moderna. Entre 1833 e 1838, Feuerbach publicou três grandes obras que, no conjunto, abrangem em detalhes autores como Bacon, Descartes, Hobbes, Spinoza, Leibniz e Pierre Bayle, além de Galileu Galilei e até mesmo o místico Jakob Böheme ${ }^{4}$. Por fim, como um esforço de conclusão do ambicioso projeto de dissecar toda a filosofia moderna, Feuerbach publica, em 1839, uma crítica específica à filosofia hegeliana, chamada Para uma Crítica da Filosofia de Hegel, com a qual o discípulo declara manifestamente sua ruptura com o sistema do mestre. De acordo com Max Wartofsky (1977, p. 49), nessas obras é que Feuerbach “descobre o seu próprio ponto de vista a partir da crítica sistemática das mais importantes figuras da filosofia" e ganha acúmulo sobre um tema dominado por Hegel - nomeadamente, as implicações mútuas entre filosofia e história. Só então ficam sedimentados os princípios com que o autor construirá a filosofia humanista e radical de $A$ Essência do Cristianismo. ${ }^{5}$

A presente resenha e a tradução em anexo tratam da introdução $(\S 1$ a $\S 8)$ da primeira dessas obras histórico-filosóficas de Feuerbach, A História da Filosofia Moderna de Bacon de Verulâmio a Benedito Spinoza, de $1833 .{ }^{6}$ Nela, antes de dissecar cada um dos sistemas filosóficos modernos, Feuerbach elabora sua própria visão da história do mundo na qual o

\footnotetext{
${ }^{4}$ Ao todo, as obras de Feuerbach sobre história da filosofia são: História da Filosofia Moderna de Bacon de Verulâmio a Benedito Spinoza (de 1833); História da Filosofia Moderna: exposição, desenvolvimento e crítica da filosofia de Leibniz (de 1837) e, finalmente, Pierre Bayle: em seus momentos mais interessantes para a história da filosofia e da humanidade (de 1838). Infelizmente, nenhuma dessas obras tem tradução para o português ou sequer para o inglês ou o espanhol.

${ }^{5}$ O professor norte americano Max Wartofski (1977, p. 197) afirma, sobre A Essência do Cristianismo de Feuerbach, que existem "dois níveis a partir dos quais a obra pode ser lida", segundo suas teses explícitas e segundo suas teses implícitas. As concepções feuerbachianas de história da filosofia são um exemplo perfeito do que o professor Wartofski entende por teses "implícitas" contidas na obra maior de Feuerbach.

${ }^{6} \mathrm{O}$ título que apresentamos é a tradução literal do original, Geschichte der Neuern Philosophie von Bacon von Verulam bis Benedikt Spinoza. A partir daqui, o texto será referido apenas como História da Filosofia Moderna de Bacon a Spinoza ou apenas História da Filosofia Moderna.
}

Revista da Faculdade de Direito - UFPR, Curitiba, vol. 60, n. 1, jan./abr. 2015, p. 247-269. 
progresso cultural da humanidade é visto à luz das principais transformações que o cristianismo introduz entre o mundo antigo e o mundo moderno. ${ }^{7}$

\section{SOBRE A INTRODUÇÃO DE HISTÓRIA DA FILOSOFIA DE BACON A SPINOZA}

Feuerbach inicia sua História da Filosofia Moderna de Bacon a Spinoza com sua visão do que seria a característica comum a todas as religiões anteriores ao cristianismo, por mais díspares que fossem entre si: o seu traço marcadamente nacional. Assim, embora afirme que a essência dessas religiões era "a unidade entre Deus e o homem, entre política e religião, espírito e natureza" (FEUERBACH, 2013, p. 7), essa unidade estaria absolutamente restrita às diferenças culturais de cada povo. As particularidades linguísticas, políticas e religiosas seriam definitivas entre os antigos e, assim, seus deuses seriam também "deuses nacionais", isto é, indissociáveis do modo de vida de cada nacionalidade. Por isso, o judeu é citado entre os povos "pagãos" embora, como religião monoteísta, o judaísmo esteja em direto contraste com as demais religiões do mundo antigo. Seu traço nacional, porém, justifica a menção ao judaísmo colocando-o ao lado das demais religiões gentílicas.

Para Feuerbach, a única exceção aos particularismos nacionais do mundo antigo seria a filosofia grega, que segundo ele, elevava os homens "acima da intolerância, das presunções e dos preconceitos nacionais, enxergando-os sob o ponto de vista cosmopolita" (FEUERBACH, 2013, p. 7). Porém, a filosofia, segundo ele, superava as particularidades e preconceitos nacionais entre os homens apenas abstratamente, no pensamento. Isto é importante porque, em A Essência do Cristianismo (FEUERBACH, 2012, p. 3), o autor define a religião como o aspecto da vida que diz respeito ao "homem completo", isto é, aquele que possui as faculdades do pensamento, da vontade e do afeto, três elementos essenciais para o ponto de vista religioso ${ }^{8}$. A filosofia pagã, por sua vez, estaria relacionada apenas com a faculdade racional do homem; incapaz, portanto, de apreendê-lo por inteiro. Assim, a

\footnotetext{
${ }^{7}$ Para quem se interessa pela relação entre a filosofia de Feuerbach e a de Hegel, o texto feuerbachiano pode ser lido em comparação com as próprias Lições sobre a Filosofia da Religião de Hegel, na qual a exposição do conceito de religião (HEGEL, 2007, v.1) vem acompanhada de uma visão histórica na qual o cristianismo é apresentado como a mais completa manifestação histórica do conceito, como a própria religião consumada (HEGEL, 2007, v. 3). Além disso, pode-se também ler o texto em comparação com a própria filosofia da história hegeliana, na qual a época "germano-cristã" é o momento final, o momento da consumação do próprio tempo histórico (HEGEL, 2004).

${ }^{8}$ A formulação de Feuerbach é muito semelhante à formulação de Schleiermacher, encontrada no $\$ 3^{\circ}$ de sua Doutrina da Fé Cristã (2011). Muito provavelmente é em Schleiermacher que Feuerbach se baseia para formular a ideia de que o ponto de vista religioso envolve essas três faculdades do homem - o pensamento, a vontade e o afeto.
}

Revista da Faculdade de Direito - UFPR, Curitiba, vol. 60, n. 1, jan./abr. 2015, p. 247-269. 
superação das contradições nacionais por meio da filosofia implicaria uma mera abstração e, de todo modo, restringir-se-ia aos círculos mais eruditos da sociedade antiga, inacessível, portanto, às camadas populares da época, formadas majoritariamente por escravos.

Ficava assim aberto o caminho para uma nova consciência que superasse as contradições nacionais das religiões pagãs de uma vez por todas, na totalidade da vida humana. Apenas a religião, e não a filosofia, seria capaz de revelar ao homem sua essência universal, não só por meio de novos conceitos racionais mas, sobretudo, por gerar no homem o sentimento e a certeza, ou melhor, a fé na essência universal do Deus único e da criatura humana. Nas palavras de Feuerbach (2013, p. 8), a contradição nacional "encontrou sua solução pela primeira vez no Cristianismo".

A ideia de que a essência universal do homem só pôde aparecer com o advento de uma nova consciência religiosa é comum às filosofias de Hegel e Feuerbach. Nas Lições sobre a Filosofia da Religião Hegel (2007, v.3, p. 109) explica o cristianismo como o evento histórico no qual o homem, finalmente, reconhece-se como ser "determinado para o universal, i.e., elevado acima de toda localidade, nacionalidade, condição, situação de vida, etc.”. Nisso, Feuerbach permanece muito próximo do pensamento hegeliano. ${ }^{9}$

Porém, em Hegel o advento da nova consciência religiosa cristã e sua elevação do homem acima das contradições nacionais é o ponto culminante não só de sua história das religiões, mas da própria história que, para Hegel, culmina com o advento da chamada época germano-cristã, como se vê na Filosofia da História (HEGEL, 2004). Para Feuerbach, ao contrário, a transformação operada pelo cristianismo com a afirmação do homem e do Deus universais é apenas o meio e não o fim do caminho. Assim, se por um lado o cristianismo surge como um novo espírito religioso universal que supera as diferenças e preconceitos culturais das religiões antigas, por outro, é justamente esse espírito cada vez mais abrangente que será a causa de uma nova contradição: a contradição entre o espiritual e o material.

\footnotetext{
${ }^{9}$ Mesmo a defesa hegeliana do conceito de Encarnação de Deus [Menschwerdung Gottes] como "ponto central especulativo" (HEGEL, 2007, v.1, p. 245) da religião cristã, isto é, como o conceito mais importante da virada histórica na consciência universal, é também mencionada implicitamente por Feuerbach. Em Hegel, a Encarnação de Deus é um momento-chave da revelação porque demonstra a preocupação de Deus em ser cognoscível pela mente humana. Assim, com a encarnação, Deus, o Ser Universal, apresenta-se como um sujeito singular, Cristo, para que a consciência dos demais homens tenha referência inequívoca e objetiva a um único caso em que Deus é homem. Esse raciocínio hegeliano é glosado por Feuerbach no $\S 1$ do texto, quando o filósofo define a consciência cristã como "uma consciência que, com o passar do tempo, se tornaria a consciência histórica mundial", mas que inicialmente reduzia-se "a uma só Pessoa, primeiramente realizando-se como um Indivíduo" (FEUERBACH, 2013, p. 8).
}

Revista da Faculdade de Direito - UFPR, Curitiba, vol. 60, n. 1, jan./abr. 2015, p. 247-269. 
Segundo Feuerbach, “com o Cristianismo ficou definida, portanto, de uma só vez, a diferença entre o espírito e a carne, o sensível e o suprassensível" (FEUERBACH, 2013, p. 8). ${ }^{10}$

Assim, Feuerbach vê no cristianismo a resolução de uma antiga contradição e a inauguração de uma nova, não entre os homens das diferentes nacionalidades e seus respectivos deuses nacionais, mas entre o único Deus, universal, e o mundo material e sensível do homem. Portanto, a tese mais fundamental de História da Filosofia Moderna será a de que o principal motor das transformações culturais entre o início da era cristã e o advento do mundo moderno está justamente no conflito entre o que é espiritual e sagrado e o que é material e mundano.

Segundo Feuerbach (2013, p. 9), a partir da Idade Média “o Cristianismo tornava-se seu desenvolvimento histórico, anticósmico e negativo", ao inaugurar um princípio cultural no qual apenas o conhecimento do que é chancelado pelas autoridades eclesiásticas tem valor reconhecido. Assim, "todo o resto deveria desaparecer como coisas vãs e negativas" e as piores consequências estariam reservadas para as belas-artes e, principalmente, para as ciências naturais, encaradas "sob o conceito de algo meramente vão e mundano, meras humanitudes" "11, negativas em relação a tudo o que não fosse chancelado pela doutrina eclesiástica e "anticósmico" porque a observação científica e a compreensão sistemática da natureza permaneciam, assim, como um interesse secundário, ou até desprezível.

Conforme impunham sua autoridade sobre a ciência, a Igreja e seu espírito negativo estenderam paulatinamente sua autoridade sobre o mundo medieval, até dominarem também o espaço político e secular do Estado. Desse modo, o que era inicialmente apenas uma atitude interna da igreja contra os conhecimentos científicos e estéticos tornou-se exercício público e aberto de controle e repressão intelectual. Há assim um movimento de negação das artes e das ciências por parte da Igreja medieval. Porém, é importante que se entenda melhor em que sentido se trata de uma negação.

Afinal, o sentido que Feuerbach atribui às palavras negação, negatividade, não se confunde com o mero aniquilamento das ciências e das artes. Ao contrário, Feuerbach (2013, p.8) reconhece que "alguns na Idade Média se dedicaram com especial zelo ao estudo da natureza" e que havia, inclusive, mosteiros em que a atividade científica era fomentada

\footnotetext{
${ }^{10}$ Assim, segundo Feuerbach (2013), enquanto o paganismo era marcado pelas contradições nacionais, muito embora sua essência fosse a "unidade entre Deus e o homem, política e religião, espírito e natureza", no cristianismo as contradições nacionais desaparecem, mas junto com ela desaparece justamente essa unidade primordial do paganismo.

${ }^{11}$ Feuerbach utiliza um neologismo, Menschtandes, ao se referir ao que é humano, isto é, não divino e sagrado, mas material e concreto, de maneira ligeiramente pejorativa, como que parafraseando a mentalidade eclesiástica, a qual ele critica. Assim, optamos por traduzir a palavra também com um neologismo, humanitude.

Revista da Faculdade de Direito - UFPR, Curitiba, vol. 60, n. 1, jan./abr. 2015, p. 247-269.
} 
mediante concessão de bolsas de estudos. Assim, o filósofo fala de "subordinação" das ciências e das artes à religião e, mesmo quando fala em repressão, trata-se mais de controlar de perto o que se produz em ciência e arte do que do aniquilamento de produções científicas e artísticas. A negatividade do cristianismo é, para Feuerbach (2013, p. 11), o espírito que enclausura os cientistas em mosteiros, intromete-se em questões de Estado para impor sua autoridade e, assim, transformar a ciência e as artes em meios para "a afirmação de sua própria glória".

Dessa forma, o espírito cristão, anticósmico e negativo, não aniquilou o espírito científico e artístico, enfim, o espírito livre. Ao contrário, o que resultou aniquilado, nessa contradição entre liberdade criativa e religião, foi o próprio cristianismo. Segundo Feuerbach (2013, p. 11), o espírito científico, inicialmente enclausurado pela Igreja Católica em seus mosteiros, "levou necessariamente à derrocada do domínio" eclesiástico como "consequência inevitável de sua parcialidade limitada e negatividade repressora". Na disputa com o espírito parcial e repressor do cristianismo, a vitória foi consagrada ao espírito de livre investigação, às artes, à ciência e à filosofia. Para Feuerbach, isso acontece em dois momentos. Primeiro, a filosofia escolástica, subordinada à Igreja, tinha a tarefa de explicar, de fundamentar racionalmente os temas principais da religião cristã, sobretudo o conteúdo das escrituras sagradas. Ou, nas palavras de Feuerbach (2013, p. 11), transformar "o objeto da fé em objeto do pensamento". Porém, com isso, a ciência que estava, inicialmente, servindo aos propósitos da Igreja, fundou "em grande parte contra a sua consciência e vontade, a autoridade da Razão”. Em outras palavras, subordinada à autoridade eclesiástica e, precisamente por isso, tendo a tarefa de racionalizar os objetos da fé, a filosofia escolástica submeteu as doutrinas da Igreja à autoridade da Razão. Algo muito parecido aconteceu com o conflito entre os dogmas da Igreja e o espírito artístico, que resultou em vantagem para as artes em termos semelhantes com os quais Feuerbach descreve o processo de emancipação da filosofia e das ciências. Pois as artes também tiveram, "como seu objeto principal, os temas da doutrina eclesiástica e, assim, transformaram o belo enquanto tal no tema do homem, inaugurando o interesse artístico enquanto tal, como fim em si mesmo" (FEUERBACH, 2013, p. 12-3).

Pouco a pouco, tanto o interesse artístico quanto o interesse científico corroeram por dentro a hegemonia cultural da Igreja Católica. Feuerbach (2013, p. 12) compara o poder eclesiástico com uma torre, no topo da qual o "pássaro do entendimento" plantou a semente da ciência e das artes que, "ao tornar-se grande como árvore, arrebentou a velha torre". Desse modo, a própria Igreja é ameaçada, segundo Feuerbach, pela fundação de um novo princípio 
destinado a governar o mundo: o espírito em que o livre pensar e o livre criar, guiados por um “desejo de luz" [Lichtdurste] (FEUERBACH, 2013, p. 11), desvencilham-se do domínio ideológico e físico do poder eclesiástico.

Porém, Feuerbach nos surpreende ao apontar qual seria este princípio. Segundo ele, embora o cristianismo e o poder despótico da Igreja venham a ser substituídos por um espírito de livre investigação científica e de criação artística, esse princípio tem, entretanto, de se manifestar historicamente como um princípio religioso. Assim, Feuerbach vê justamente no Protestantismo o início de um novo princípio de livre investigação e criação artística que suplanta a dominação parcial e violenta da Igreja.

Uma evidente objeção a ser feita seria a indagação sobre o que há de tão "novo" nesse princípio. Afinal, não se trata da continuidade da consciência religiosa cristã sob outra forma? Segundo Feuerbach (2013, p. 13), a resposta seria negativa, pois, conforme argumenta, "o Protestantismo é o novo princípio, que fala, assim, como um espírito religioso" sem, entretanto, sê-lo realmente. Em outras palavras, o Protestantismo é apenas uma aparência [Erscheinung] religiosa do espírito de liberdade investigativa e criativa. ${ }^{12}$

Para Feuerbach (2013, p. 14), o espírito que floresceu da filosofia moderna é o mesmo evocado pelo Protestantismo. Ambos são, na verdade, o mesmo espírito que "se expressa no indivíduo como independência e sentimento pessoal de liberdade, cuja consciência ou o sentimento é a divindade inata de sua essência”. Assim, pode-se, inclusive, estabelecer um ponto em comum entre a filosofia cartesiana e a reforma de Lutero. Nas palavras de Feuerbach (2013, p. 14): “enquanto Descartes diz: penso, logo existo, isto é, meu pensamento é o meu ser, Lutero diz, contudo, minha fé é o meu ser" (grifos do autor).

$\mathrm{Na}$ base da filosofia cartesiana e da religiosidade luterana está a certeza de si e a dúvida em relação ao mundo exterior. Afinal, enquanto a filosofia nasce da "dúvida sobre a realidade e a verdade da existência sensível”, de modo semelhante, o Protestantismo, como fé religiosa, nasce também da "dúvida sobre a realidade de uma existência histórica dominada sob a autoridade da Igreja" (FEUERBACH, 2013, p. 14). Para Feuerbach (2013, p. 14), a “certeza do espírito sobre sua própria objetividade" em contraposição à dúvida sobre a

\footnotetext{
${ }^{12}$ Aqui, há uma diferença essencial em relação ao hegelianismo. Hegel (2007, v.1, p. 131-2) reconhece que a Igreja Católica, durante a Idade Média, enclausurou e dominou as ciências, as artes e até mesmo a política, realizando a "clivagem", em suas próprias palavras, entre o mundo secular e a religião cristã. Entretanto, para ele, longe de ser uma ruptura com a religião cristã, o Protestantismo é o momento em que finalmente o verdadeiro e original espírito do cristianismo é revelado como a afirmação da liberdade do sujeito e de sua unidade ou reconciliação com Deus. A própria formulação segundo a qual a história culmina no período "germano-cristão" faz referência não apenas à conversão dos povos germânicos por Carlos Magno no século oitavo, mas, principalmente, pela religiosidade inaugurada por Lutero.
}

Revista da Faculdade de Direito - UFPR, Curitiba, vol. 60, n. 1, jan./abr. 2015, p. 247-269. 
realidade externa e a autoridade eclesiástica, é "o que define o Protestantismo em sua estreita relação com a filosofia moderna", o que define, portanto, a relação entre René Descartes e Martinho Lutero.

Porém, o novo princípio da racionalidade moderna que se iniciava com o Protestantismo teria as escrituras sagradas como seu limite máximo, embora sua missão fosse continuar "até atribuir a razão cognoscente como fundamento de toda a filosofia". Assim, o que começa a se expressar como religião Protestante acaba por gerar "a filosofia como seu verdadeiro fruto"; fruto que, para Feuerbach, será "muito diferente de suas sementes" (FEUERBACH, 2013, p. 14). A metáfora expressa que, num determinado momento da história moderna, haverá uma diferenciação entre o impulso original da consciência moderna, o Protestantismo, de um lado, e, de outro, a filosofia moderna.

Apenas a partir desse momento nasce a filosofia moderna propriamente dita. Assim, se Lutero foi o fundador do novo princípio, Bacon e Descartes serão os responsáveis pelo passo seguinte, no qual esse mesmo princípio romperá, inclusive, com as sagradas escrituras. Esse passo será dado na medida em que o novo princípio da autoridade da razão passa a deterse não mais sobre os escritos bíblicos, mas sobre a filosofia antiga. Assim, surge a reabilitação das obras antigas da ciência e da filosofia pagãs. Segundo Feuerbach (2013, p.15), "Platão, Aristóteles e os outros sistemas filosóficos e diferentes obras do mundo antigo foram, por essa razão, esmiuçados com grande entusiasmo".

O passo fundamental da consciência moderna em direção à ruptura com a forma religiosa de sua expressão foi, assim, dado pela reabilitação do ponto de vista empírico. Desse modo, a filosofia moderna, enquanto tal, nasce com os pensamentos de René Descartes e Francis Bacon na medida em que ambos realizaram, pela primeira vez, o movimento em direção à livre investigação científica dos fenômenos e leis naturais. Descartes é o primeiro a definir explicitamente a observação empírica da natureza como objetivo principal da filosofia. Bacon, antes dele, inicia esse percurso de modo ainda imediato e intuitivo ao fazer "da necessidade inescapável da experiência uma lei para si próprio e uma reivindicação necessária" expressando, “com severidade implacável, o princípio da experiência como método" (FEUERBACH, 2013, p. 17).

Naturalmente, a reconstrução histórica de Feuerbach dos sistemas dos principais filósofos não para por aqui, mas será objeto de três extensos volumes sobre o assunto. A introdução, porém, traz uma interessante reconstrução da grande transformação cultural inaugurada pelo cristianismo. Assim, o filósofo parece mostrar como a história do 
cristianismo está pressuposta na história da filosofia moderna de modo a deixar em aberto o seu progresso no tempo. Feuerbach, ao contrário de Hegel, entende o cristianismo não como um ponto final, ou um momento de consumação [Vollendung] da história, mas como um momento intermediário de uma história em andamento - a história da liberdade de consciência artística, científica e filosófica.

Ao publicar sua A Essência do Cristianismo, em 1841, Feuerbach conquistaria o entusiasmo de toda uma geração, incluindo Marx e Engels, ao propor que a consciência humana poderia acordar do sono profundo imposto pela consciência religiosa ao perceber que Deus é a projeção daquilo que o homem mais estima em si mesmo, é a espécie humana alienada de si. Na introdução de A História da Filosofia Moderna de Bacon a Spinoza vemos Feuerbach assentar fundamento desse humanismo radical na ideia de que a história da filosofia é o próprio desdobramento de um impulso original do homem pelo conhecimento e pelo autoconhecimento, um “desejo de luz".

\section{REFERÊNCIAS}

BRECKMAN, Warren. Dethroning the Self: Marx, the Young Hegelians and the Origins of Radical Social Theory. Nova York: Cambridge University Press, 2001.

FEUERBACH, Ludwig. Geschichte Der Neuern Philosophie von Bacon von Verulam bis Benedikt Spinoza. Berlin: Holzinger, 2013.

. The Essence of Christianity. Nova York: Cambridge University Press, 2012.

. Das Wesen des Christentums. Berlin: Holzinger, 2013.

. Towards a Critique of Hegel's Philosophy. In: STEPELEVICH, Lawrence. The Young Hegelians, an Anthology. Nova York: Humanity Books, 1999.

FEUERBACH, P. J. A. Caspar Hauser: An Account of an Individual Kept in a Dungeon, Separated from all Communication with the World, From Early Childhood to About the Age of Seventeen. Boston: Allen and Ticknor, 1932.

HEGEL, G. W. F. The Philosophy of History. Mineola: Dover, 2004.

Lectures on the Philosophy of Religion. Volumes 1, 2 e 3. Nova York: Cambridge University Press, 1989.

RADBRUCH, Gustav. Paul Johann Anselm Feuerbach: ein Juristenleben. Viena: Springer, 1934.

SCHLEIERMACHER, Friedrich. The Christian Faith. Berkley: Apocryphile Press, 2011. 
TOEWS, J. E. Hegelianism: the Path towards Dialectical Humanism. Nova York: Cambridge University Press, 1989.

WARTOFSKY, Max. Feuerbach. Nova York: Cambridge University Press, 1977. 


\begin{abstract}
ANEXO
Tradução de FEUERBACH, Ludwig. Geschichte der Neuern Philosophie von Bacon von Verulam bis Benedikt Spinoza. Berlin: Holzinger, 2013.
\end{abstract}

\title{
$\S 1$
}

A essência do paganismo era a unidade entre religião e política, espírito e natureza, Deus e o homem. Porém, o homem pagão não era o homem puro e simples, mas o homem nacional, particular: o Grego, o Romano, o Egípcio, o Judeu e, consequentemente, também o seu Deus [era] nacional, particular, determinado, um ser contrário ao ser de outros deuses e de outros povos - um ser, portanto, em contradição com o Espírito, que é a essência da Humanidade e, portanto, é a unidade geral de todos os povos e homens.

A superação dessa contradição, no paganismo, foi a Filosofia pagã, pois ela elevou os homens de então acima de seu isolamento e autossuficiência nacionais, acima da intolerância, das presunções e dos preconceitos nacionais, encarando-os de um ponto de vista cosmopolita. Portanto, [a filosofia] era, deste modo, o poder de expansão do espírito pensante, de uma consciência nacional e limitada para uma consciência universal: um destino desastroso para os deuses do paganismo e o fundamento espiritual do declínio das particularidades folclóricas pagãs como poderes divinos que dominavam o mundo. Entretanto, a filosofia superou essa contradição apenas no pensamento; apenas, portanto, de maneira abstrata.

A verdadeira resolução dessa contradição aparece, pela primeira vez, no Cristianismo. Nele, o Logos sarx, i.e., a razão universal, torna-se aquilo que todos os homens e nações compreendem. Todas as hostilidades e antagonismos entre os homens são resolvidos de modo universal e puro, e assim, tal qual o ser divino, o ser humano torna-se também objeto da certeza imediata - objeto da Religião. O Cristo não é outra coisa senão a consciência humana da unidade entre seu ser e o ser divino, consciência que, enquanto ainda estava por vir o tempo em que seria a consciência histórica mundial, expressava-se como fato imediato, reduzindo-se a uma só Pessoa, realizando-se, primeiramente, como um Indivíduo, enquanto o resto do mundo, repousando ainda sob as trevas das contradições entre as particularidades dos povos, estava, necessariamente, em oposição [a ele] como o Criador de uma nova era mundial. 
Foi assim que, no Cristianismo, Deus como Espírito tornou-se objeto para os homens; pois somente Deus, que se mantém em tal pureza e generalidade, às quais ele é levado pelo Cristianismo, somente o Universal, a Essência purificada de todas as diferenças e particularidades, sejam elas nacionais ou naturais, é Espírito. O Espírito, porém, não aparece na carne, mas move-se apenas naquilo que é espírito. Com o Cristianismo fica, assim, estabelecida, de uma vez por todas, a diferença entre espírito e carne, sensível e suprassensível - diferença que, por sua vez, conforme o Cristianismo avançava em direção aos momentos posteriores de seu desenvolvimento histórico, aprofundou-se em oposição, ou mesmo em dicotomia entre espírito e matéria, Deus e o mundo, o suprassensível e o sensível. E assim, nessa oposição que determinava o suprassensível como a única [realidade] existente e o sensível como o inexistente, o Cristianismo tornava-se, no curso de seu desenvolvimento histórico, anticósmico e negativo; recuava diante da natureza, dos Homens, da Vida, do Mundo em geral e não do que é banal, mas do que é Positivo no Mundo, sendo em sua verdadeira essência uma religião da ignorância e da negação.

\section{$\S 2$}

Conforme esse espírito religioso negativo se impunha como ser verdadeiro e absoluto, o espírito dominante da época, perante o qual todo o resto deveria desaparecer como coisas banais e negativas, adveio, como consequência inevitável, o perecimento não apenas das belas-artes e das artes plásticas, mas principalmente das ciências em si e para si. Nem as inúmeras guerras e intempéries daquele tempo, nem a brutalidade natural daqueles povos, mas apenas essa tendência religiosa negativa foi o fundamento efetivo, ou pelo menos espiritual, de sua decadência e declínio. Com isso, as artes e as ciências submeteram-se ao espírito dessa tendência, renegadas sob o conceito de algo meramente vão e mundano, meras humanitudes. ${ }^{13}$

Além disso, a própria Natureza, segundo a lei dessa tendência, teria de desaparecer na noite do esquecimento e da ignorância. Como poderia o Deus limitado, que vive somente em si, retirado da essência do mundo, o Cristo vivo, ter algum sentimento pela natureza e seu estudo? A natureza, cuja forma essencial é o sensível, exatamente o que existe para ser negado, que se resume àquilo perante o qual o divino recua, tem para Ele apenas o significado de algo finito, vão e insubstancial [wesentlosen]. Como poderia, portanto, o Espírito

\footnotetext{
${ }^{13}$ Feuerbach utiliza um neologismo, Menschtandes, ao se referir ao que é humano - isto é, não divino e sagrado, mas material e concreto -, de maneira ligeiramente pejorativa, como que parafraseando a mentalidade eclesiástica a qual ele critica. Assim, optamos por traduzir a palavra também com um neologismo, humanitude. Revista da Faculdade de Direito - UFPR, Curitiba, vol. 60, n. 1, jan./abr. 2015, p. 247-269.
} 
concentrar-se nela, o assunto mais grave, empenhando-se persistentemente sobre o que, para ele, não tem senão a importância de algo finito e fútil? Além disso, que interesse teria a criatura temporal [zeitliche Kreatur], a criatura miserável, em conhecer outra coisa, quando já se conhece o Criador [Schöpfer]? Como poderia a criatura, que já vive em relações familiares com o seu Senhor, desmerecer-se tanto a ponto de dar-se com a criada? E que outra parte caberia à natureza nessa religiosidade negativa, senão a função e a posição de criada de Deus? A abordagem teológica da natureza se resume unicamente a essa visão, mas esse não é o modo objetivo e físico de se penetrar e abordar a natureza.

A natureza estava, assim, para o espírito humano, numa posição tal que seus olhos não poderiam enxergá-la. Nos próprios lugares consagrados ao culto religioso daquele tempo a luz não caminhava por meios transparentes, mas atravessava coloridos vitrais. Tal qual a Luz pura para o fiel, a Natureza e o Mundo seriam para a comunidade, que se voltava para Deus, algo estranho e perturbador e, assim, não poderia ela [a comunidade] suportar a Luz da natureza do mesmo modo com que suportava a luz da devoção, cuja chama inflama o espírito apenas no escuro, no ocultamento da natureza. Assim, enfraqueceu-se a luz natural daquele tempo e, onde quer que o espírito despertasse novamente para o pensamento e os olhares se voltassem para o aprendizado da natureza, ela iluminava o homem apenas de maneira embaçada, fragmentada e mediada pela física aristotélica, porque o homem temia a infalibilidade de sua religiosidade negativa, receoso de ver com os próprios olhos e colher com as próprias mãos o fruto da árvore do conhecimento.

Apesar de alguns, na Idade Média, dedicarem-se com especial zelo ao estudo da natureza, apesar, principalmente, de lhes serem ofertadas bolsas de estudo pelos Mosteiros e Escolas que os recebiam e avaliavam, ainda assim permaneceram as ciências subordinadas às ocupações secundárias do Espírito humano, relegadas a uma importância limitada e precária. Era assim que deveriam permanecer enquanto fosse o Espírito religioso a maior autoridade histórica, o poder legislativo, e a Igreja, o seu poder executivo.

A única coisa imanente ao espírito religioso exclusivo, isto é, dele inseparável, sua essência conforme o conhecimento científico, era a Teologia, na qual o conteúdo da fé foi trazido à consciência do entendimento [e] por ela dissecado, determinado, ordenado e iluminado. Entretanto, com a determinação do conteúdo da fé pelo pensamento, esse conteúdo 
tornou-se objeto para a consciência pensante, para o entendimento analítico e resolutivo. Com isso, a consciência pensante tornou-se, ao mesmo tempo, independente da substância da fé religiosa, ela própria um objeto que, [embora] inerente ao conteúdo da fé, é ao mesmo tempo um objeto pra o Pensamento enquanto tal e, assim, a Teologia transformou-se em Filosofia. Porém, uma vez que o pensamento, que não possuía qualquer privilégio público, não era senão impulsionado apenas pelas mãos do princípio religioso, vigente como o princípio supremo, a mais alta e última autoridade, [uma vez que o pensamento] não era, portanto, sancionado, e os assuntos da Dogmática, dos ensinamentos religiosos, os terminus a quo et ad quem, o non plus ultra eram a última fronteira do Espírito humano, embora individualmente [pudessem ser] ignorados. Assim permaneceu o conteúdo da Teologia eternamente como tema principal do Espírito pensante, e a Filosofia, como tal, conquistou para si apenas a condição de uma tradição, à qual faltava, portanto, aquela força produtora livre, aquela atividade fundamentalmente criativa, aquela autópsia da natureza e autonomia da razão que distinguem a filosofia grega da filosofia dos novos tempos e que constituem o caráter peculiar da Filosofia em absoluto. Vem daí aquele Espírito de abstração, aquela mentalidade lógicometafísica, que por si só caracterizavam a essência e o Espírito da chamada escolástica ou Filosofia escolástica aristotélica; assim, purificado de todas as ciências filosóficas, com exceção da Lógica e da Metafísica de então, o espírito com que tudo deveria ser tratado e considerado era o espírito formal da lógica metafísica. Disso decorre a monotonia e a uniformidade de sua história que, ao negar o qualitativo, avançava sucessivamente de embate em embate, surgindo, assim, uma história real apenas quando seu lento curso era interrompido por desavenças fundamentais a respeito de seus consensos: a história das Filosofias antiga e moderna é como água parada, quando arrastada por um rio caudaloso. Assim, carecia à estreiteza de espírito e à falta de gosto, que caracterizam a Forma, toda grandeza, genialidade e originalidade; por isso a completa falta de princípios, com que a Alma organizadora e fomentadora se tornaria o Todo coerente consigo mesmo e a si mesmo correspondente, surgindo a partir daí, sem necessidade, sem massa determinada e definida, um espírito de distinção, atomização e compartilhamento ao infinito, que deveria conduzir o finito a um mero formalismo, à resolução de todos os conteúdos, ao vazio absoluto e às aversões e relutâncias relacionadas à Escolástica. 
Na medida em que o espírito religioso negativo da Igreja se elevou a um poder mundialmente dominante, a atitude, inicialmente apenas interna, de desrespeito e desprezo por tudo o que fosse considerado mundano, finalmente culminou na repressão mundana e violenta ao mundano, a ponto de a supremacia da Igreja, como epítome do clero, usurpar o Estado, como epítome do Secular. Arrefeceu-se de tal forma a negatividade da Igreja contra as artes e as ciências, por fim enredadas e raptadas, destituídas de qualquer liberdade ou independência, que ela [a Igreja] as tornou apenas meios para a sua própria glória, ou então, serviu-se delas como de um acessório. Porém, esse espírito, e somente ele, apenas aparentemente intrometido, levou à derrubada do reinado espiritual da religião negativa e de sua existência manifesta, a Igreja, consequência inevitável de sua parcialidade limitada e de sua negatividade repressora.

Embora se saiba que a filosofia escolástica estivesse a serviço da Igreja, na medida em que ela reconhecia, provava e defendia suas próprias posições, partia de um interesse científico que despertou e deu origem a, posteriormente, um espírito de livre investigação. Ela [a filosofia escolástica] transformou o objeto da fé em objeto do pensamento, elevou o homem da esfera da fé incondicional à esfera da dúvida, da investigação e do saber e, enquanto buscava provar e confirmar o fundamento das questões [que pertenciam à] mera crença autoritária, fundava, em grande parte contra sua consciência e vontade, a Autoridade da Razão. Com isso, trazia ao mundo um outro princípio, diferente daquele da antiga Igreja, o princípio do Espírito pensante, da autoconsciência da Razão ou, pelo menos, preparava-lhe o caminho. Mesmo a deformação e o lado obscuro da escolástica, as muitas questões absurdas nas quais, em parte, ela caiu, mesmo as milhares de distinções desnecessárias e aleatórias, suas curiosidades e sutilezas, deveriam ser deduzidas de um princípio racional, de um desejo de luz [Lichtdurste] e de um espírito investigativo que, naquele tempo, porém, apenas e tão somente poderia se expressar sob a lei opressiva da velha mentalidade eclesiástica. Todas as suas questões e distinções não eram outra coisa senão fissuras e fendas perturbadoramente abertas no velho muro da Igreja para a fruição da luz e a passagem do ar fresco; não eram senão manifestações do impulso prático do espírito pensante que, quando está encarcerado, retirado do âmbito dos objetos racionais e das atividades que lhes são apropriados, eles lhe parecem tão marginais, tão indignos de atenção para a sua empresa, que ela os preenche, com as formas mais absurdas, infantis e perversas, até mesmo por falta de meios. Apenas onde a 
própria escolástica não era senão uma relíquia histórica morta, uniu-se ela, em desacordo com seu significado e determinação originais, com as coisas da velha doutrina eclesiástica, tornando-se, assim, o inimigo mais cruel das melhores mentes despertas.

\section{$\S 5$}

Assim como a filosofia escolástica, a Arte, embora estivesse, igualmente, apenas a serviço da Igreja, e fosse vista como uma edificação desta - ou meio de glorificação da Igreja - [também] produziu um princípio oposto ao espírito religioso anticósmico. A posição de uma serviçal submissa jamais poderia caber à arte por muito tempo porque, afinal, desse modo permanecia imperfeita, aquém do auge de sua consumação. Devido ao fato de servir, ainda que parcial e externamente, aos propósitos da Igreja, a arte também adotou como seu objeto principal os temas da doutrina eclesiástica, mas, com isso, o belo enquanto tal tornou-se um tema para o homem e surgiu, assim, o interesse artístico enquanto tal, como fim em si mesmo. Assim, despertou o mais alto e independente sentimento, sentimento livre de interferências externas, pela mais pura beleza e pela humanidade; novamente o homem foi levado à contemplação das magníficas criações de seu espírito, de seu sentimento de si, da consciência de sua autonomia, de sua nobreza espiritual, de sua imanente, natural e singular semelhança com Deus, do sentimento pela natureza, seu estudo e sua observação, por uma visão correta da verdade, pelo conhecimento da realidade e da substancialidade de tudo o que, de acordo com o espírito religioso negativo, era, antes, tratado como algo vão e ímpio [Ungöttliches]. A arte era a encantadora Maia, a quem o espírito obscuro da Igreja, assim como certa vez o velho Brahma, formou a partir da melancolia e da misantropia expelidas de sua cabeça; a arte era a Sedutora hipócrita que conduzia os homens aos mais elevados pináculos da Igreja, para que seu peito oprimido e sufocado aqui ganhasse respiração livre que lhe permitisse inalar, no céu, aromas frescos de sentimentos e crenças puramente humanos, e escancarar tais sentimentos diante de seus olhos, para que alcançasse, no esplendor do mundo terreno, um outro mundo, o mundo da liberdade, da beleza, da humanidade, da diferença e da ciência. Assim como a árvore que se sustenta sobre uma torre, suspensa a partir de rochas rígidas, também a arte veio até a Igreja e seu espírito, como semente trazida até o alto pelo pássaro do entendimento; porém, ao brotar e florescer como planta, mostrou-se que, decerto, não era coisa inofensiva e, ao tornar-se grande como árvore, arrebentou a velha torre. Foi assim que, o que era aparentemente apenas espírito servil da mentalidade religiosa negativa produziu, a 
partir dele, o espírito que se lhe contradizia; nomeadamente, o espírito cientifico, puramente humano, livre, autoconfiante, todo-amoroso e todo-abrangente, onipresente, universal. Esse espírito degradou a mentalidade negativa da religião e a destronou de sua dominação mundial, encurralada em seus estreitos limites. Para além desses limites, porém, apontou o motor contínuo da História para um lugar em que o novo espírito podia se constituir como princípio e essência do mundo, em fundamento de um novo tempo.

\section{$\S 6$}

$\mathrm{Na}$ medida em que vem ao mundo como um novo princípio, ele precisa, ao mesmo tempo, falar como um princípio religioso; apenas assim pôde operar no mundo uma ruptura aterrorizante, pois só assim tornou-se coisa comum para os ânimos que dominavam o mundo. É somente assim que a coragem irresistível pode dominar o indivíduo, em nome da qual o espírito se coloca em atividade ao reconhecer em Deus esse ato de deserção do antigo princípio e manifestar-se como uma religião, antes que toda a violência externa desapareça como [algo] impotente. O Protestantismo é o novo princípio, que fala, assim, como um espírito religioso. O mesmo espírito que a filosofia escolástica evocou, na medida em que foi um meio de libertação da autoridade externa e da pura fé da Igreja; [o mesmo espírito] que trouxe para o mundo real, por meio da arte, a ideia de beleza em sua independência e autossuficiência e tornou visível para o homem o caráter divino de sua criatividade; que despertou o Pagão, condenado e exilado ao inferno do espírito religioso negativo, trazendo e concedendo-lhe a vida que o Cristão, após uma longa e dolorosa separação, finalmente reconheceu e abraçou como seu parente mais próximo; que criou a vida cívica livre, conciliando o sentido prático do mundo, engenhosamente inventivo, com o presente, embelezou e enobreceu a vida, aumentou a autoconfiança dos homens e desenrolou a expansão de sua atividade e de seu estado de alerta; que venceu a guerra dos príncipes contra o domínio arrogante da hierarquia da absoluta espontaneidade, autonomia e autarquia do Estado, consequentemente contra seu chefe, que os concentrava em uma só pessoa; o mesmo espírito, e não outro; $o$ espírito, que se expressa no indivíduo como independência e sentimento pessoal de liberdade, cuja consciência ou o sentimento é a divindade inata de sua essência e assim reconhece a força, não exterior, do poder vinculativo da consciência de decidir e determinar por si mesmo, o que deve ser o poder vinculativo da verdade, esse e não outro espírito, digo eu, foi o evocado pelo Protestantismo, que, assim, é visto como apenas 
um aspecto particular e especial dele. Uma vez que o Protestantismo surgiu da essência desse mesmo espírito, que floresceu da época e da filosofia modernas, permanece em relação íntima com elas, embora naturalmente ocorra uma diferença específica entre a forma com que o espírito do mundo moderno se realiza como princípio religioso e como princípio científico. Enquanto Descartes diz: "penso, logo existo", isto é, meu pensamento é o meu ser, Lutero diz, contudo, "minha fé é o meu ser". Assim como a unidade entre pensamento e ser que, como tal, é a unidade do espírito, cujo ser é apenas pensamento, é reconhecida e estabelecida como princípio da filosofia, também se reconhece essa unidade entre a fé e o ser, a qual se expressa como religião. Erigida como princípio dos tempos modernos, manifestada como tal pela filosofia, com a dúvida sobre a realidade e a verossimilhança da existência sensível, começou, assim, a se expressar como fé religiosa, com a dúvida sobre a realidade de uma existência histórica sob a autoridade da Igreja. E essa intensa força espiritual, a certeza do espírito sobre sua objetividade, é o que define o Protestantismo em sua estreita relação com a filosofia moderna.

No Protestantismo, portanto, por assim dizer, o logos do cristianismo tornou-se, pela primeira vez, carne; o logos, que no período anterior fora destruidor, oculto, recluso, transcendental, tornou-se espírito verbal, isto é, nele o cristianismo perdeu sua negatividade e abstração, tornou-se [o $\operatorname{logos}$ ] no Homem, ao reconhecer-se nele como idêntico à sua essência, à sua vontade e ao seu espírito, e não como limitação e negação de suas necessidades espirituais e naturais.

O princípio do espírito pensante, no qual o Protestantismo se baseia e do qual ele surgiu, revelou mais de perto a própria matéria do pensamento, com o discernimento e a crítica do inessencial e do essencial, do arbitrário e do necessário, do que é apenas histórico e do que é seu impulso original, do conteúdo da religião simplificada e dos componentes simples e essenciais decorrentes de sua análise, da colorida e dispersa multiplicidade e dos diversos objetos religiosos de antes e de sua redução a um só objeto. Por meio dessa redução à unidade, o pensamento abriu espaço e avançou pelo caminho da dissipação de todos os pontos de vista que impedem o homem de enxergar seus objetos de perto e de longe; isso libertou a religião de muitos - e a racionalidade exterior elevou-se à condição de objeto da reflexão, do espírito e, assim, a vitalidade e a atividade dos homens absorveram e consumiram a Igreja, reconhecendo o poder secular, em vez de a Igreja, como lei e autoridade dominantes. Assim, não foi apenas do resultado de circunstâncias e condições externas, mas de uma necessidade interna ao próprio Protestantismo, que se revelou, pela primeira vez, o 
significado histórico da filosofia do mundo moderno e seu desenvolvimento livre, fértil e cada vez mais abrangente. Afinal, a redução da religião em seus elementos mais simples, que o Protestantismo tinha iniciado pela primeira vez, mas fora interrompido ao esbarrar na Bíblia, deveria necessariamente continuar até os elementos últimos, originais e supra-históricos, até atribuir à razão cognoscente o fundamento de toda a filosofia, assim como de toda a Religião. Assim se deveria gerar necessariamente, a partir do Protestantismo, a filosofia como seu verdadeiro fruto, que, é claro, é muito diferente de suas sementes e que, para o olho comum, que atenta apenas para as características externas e semelhanças palpáveis, não possuía nenhuma relação interna com ela.

\section{$\S 7$}

Porém, antes que o espírito pensante e autoconsciente, desperto recentemente, chegasse ao poder e à capacidade de criar a si próprio, de definir novos conteúdos e objetos para si, ele tinha antes de se comportar passivamente num mundo já acabado e construído, com o qual se confrontou como [sua] realidade, e transformar, o que nele ainda estava presente apenas como busca e desejo, no objeto que impulsionaria sua formação e desenvolvimento. Como a primeira intuição do homem é a intuição de seu ser como de um outro, isto é, primeiro ele intui e reconhece o seu ser e a si próprio em outro e atinge, portanto, a autoconsciência de sua própria essência humana em outro ser humano, que é igual a seu próprio ser, da mesma forma o espírito humano na época moderna apenas alcançou a intuição de si como um objeto, por meio do reconhecimento e da assimilação do espírito das obras da antiguidade clássica, as quais estavam intimamente relacionadas com sua autoconsciência e produtividade. Antes de se tornar produtivo, [o homem] precisou reproduzir em si mesmo um mundo que era o seu próprio espírito, sua essência e sua origem. Platão, Aristóteles e os outros sistemas filosóficos e diferentes obras do mundo antigo foram, por essa razão, esmiuçados com grande entusiasmo, assimilados e devorados com tal ânsia, porque o espírito tomado por esse entusiasmo encontrou neles a satisfação de sua necessidade espiritual mais intima, neles celebrou a redenção e a ressurreição de sua própria razão, porque o recémdesperto espírito livre, universal e pensante, reconheceu naquelas obras o produto de si mesmo. Apenas com essa intuição e apropriação de um mundo cujo espírito, embora fosse objetivo, palavra dada, palavra proferida, era, ainda assim, palavra enunciada pela alma, que disse perfeitamente o que deveria e queria dizer a respeito do coração, sem ainda possuir as 
habilidades e capacidades necessárias para dizê-lo por si só. Assim, voltou-se o homem para si próprio, desceu às suas próprias profundezas, uniu-se a si próprio, sua única fonte de autoprodução e atividade. Pois um espírito produtivo é apenas aquele que não se detém sobre uma determinada substância, sobre um mundo tradicional que não é sentido ou reconhecido como seu, mas como um outro que é exterior a ele, e sim sobre um mundo que está em unidade com ele.

\section{$\S 8$}

Como o espírito pensante, livre e universal foi retomado e teve diante de si um ser-aí objetivo, deu-se um episódio necessário, pelo qual nós retornamos ao antigo mundo pagão para honrar novamente a Natureza, abandonada à posição miserável de mera criatura, para mais uma vez exibir a glória e a majestade de sua infinitude e essencialidade. A Natureza que, por um lado, afundou na noite da ignorância completa e do esquecimento durante a Idade Média, por outro lado, apenas indiretamente e sob a mediação turva, foi o objeto de uma física tradicional e, além disso, mal compreendida, tornou-se agora um objeto imediato de observação e, sua pesquisa, um objeto essencial da filosofia e da experiência. Pois a filosofia ou o conhecimento da natureza, do ser que difere do espírito, não é imediatamente idêntica ao espírito, mas conhecimento mediado, condicionado à experiência, por meio da investigação, observação e percepção sensíveis. [A Natureza] é uma questão da própria fillosofia e uma questão essencial do pensamento humano em geral.

As ciências naturais tinham primeiramente, no mundo moderno, um significado histórico, formadas primeiramente a partir de uma relação histórica, de uma série contínua de descobertas e invenções. Uma questão, porém, que tinha primeiramente importância de efetividade histórica, alimentou-se assim de verdadeiros sucessos e chegou pela primeira vez a um avanço qualitativo, relacionado com a necessidade inerente de seu progresso histórico, quando obteve em si um princípio global objetivo em seu fundamento. Afinal, apenas assim ela é necessária, e tão somente essa necessidade objetiva é o seu fundamento, a qual progride em seu desenvolvimento produtivo, frutífero e bem sucedido, simplesmente porque não mais deriva e depende de meras aspirações subjetivas e inclinações particulares. Esse espírito objetivo - e princípio global dos tempos modernos, que se assenta sobre a necessidade e sobre o fundamento de uma nova ciência empírica, não era outra coisa, em geral, do que simplesmente a autossuficiência e a livre consciência alcançadas pelo espírito pensante. 
A experiência (no sentido da experiência científica, e não no sentido da experiência da vida cotidiana) é nomeadamente, não como por vezes se insiste em apresentar, um resultado e uma compreensão imediata de si mesmo, um ponto de vista infantil, e muito menos um trabalho original, fundamentado em si mesmo, senão um ponto de vista que pressupõe essencialmente um princípio espiritual determinado como seu fundamento. $\mathrm{O}$ ponto de vista da experiência reside, como se entende, em primeiro lugar no impulso de querer conhecer e abraçar a natureza, um impulso que se revela, novamente, na consciência da contradição entre o ser e a aparência, na dúvida de que a coisa é realmente como ela se mostra, de que a essência da natureza esteja absoluta e incondicionalmente ao alcance das mãos, e sob o domínio dos sentidos, tendo a crítica e o ceticismo a sua frente; portanto, os fundadores da filosofia moderna, Bacon e Descartes, começaram, explicitamente, por este ponto de vista, o primeiro fazendo da rejeição aos preconceitos e opiniões previamente dominantes a precondição para o conhecimento da natureza; o segundo em sua demanda de que, para começar, devemos duvidar de tudo. Porém, esse ceticismo está, mais uma vez, fundado no fato de que o espírito, no Homem e com o Homem, apreende a diferença entre o indivíduo e a natureza; que o espírito conhece apenas essa sua diferença com a natureza como sua essência e, nessa diferenciação de si, faz da natureza o objeto intrínseco de seu pensamento. Somente sob a base desse processo o Homem tem, primeiramente, seu verdadeiro interesse, impulso e desejo de avançar na investigação e exploração da natureza, pois é precisamente nessa distinção que ele, pela primeira vez, alcança a visão da natureza como o jovem alcança a visão da virgem; quando ele chega à consciência da diferença, chega ao irresistível impulso e estímulo para reconhecê-la e torna-se, o conhecimento da natureza, seu maior interesse.

O ponto de vista da experiência toma, assim, como seu fundamento, o princípio espiritual que, de modo determinado, embora altamente imperfeito e subjetivo, expressou-se e foi levado à consciência do Homem em Descartes. O pai espiritual e mediado das ciências naturais modernas é, portanto, Descartes. Pois, embora Bacon fosse anterior e estivesse sensível e visivelmente em uma posição muito próxima do ponto de vista da experiência, com o qual está, evidentemente, relacionado, ele ainda fundamenta sua essência sobre o princípio da autoconsciência, percebido em sua diferença com a natureza como essência objetiva a ser traduzida pelo espírito, princípio que, como tal, Descartes transformou, pela primeira vez, em objeto da filosofia. O pai imediato e sensorial das ciências naturais modernas é Bacon, que fez 
da necessidade inescapável da experiência uma lei para si próprio e uma reivindicação necessária, e expressou, com severidade implacável, o princípio da experiência como método.

\title{
A DESIRE FOR LIGHT: CHRISTIANITY AND THE EMERGENCE OF MODERN PHILOSOPHY IN LUDWIG FEUERBACH
}

\begin{abstract}
This is a review of Ludwig Feuerbach's book introduction Geshichte der Neuern Philosophie von Bacon bis Spinoza. The original text is in German, the review is in Portuguese. However, we present here, attached, the translated text, also unpublished and original. In 1841's The Essence of Christianity, Feuerbach presents in a most complete way his own version of the radical humanism which excited the young hegelians of his generation. However, it is between 1833 and 1838 that Feuerbach formulates his own philosophical point of view from the critique of the major philosophical systems of modernity. The History of Philosophy from Bacon to Spinoza, published in 1833, is the first of his historicalphilosophical works which, apart from the critique of the philosophers indicated by the title, presents also a singular feuerbachian vision of history as a whole, showing how modern philosophy emerges from the inherent contradictions of the Christian religious spirit.
\end{abstract}

KEYWORDS: Christianity. Critique of Religion. History of Modern Philosophy. Ludwig Feuerbach. Philosophical critique. 